\title{
Investigation and Study on the Improvement of University Students' Employment Ability in Liaoning Province from the Perspective of Supply Chain Management
}

\author{
Yue QI, Wei-hua YANG ${ }^{*}$ and Yang-yang SI \\ Dalian, Liaoning Province, China, Dalian Polytechnic University \\ ${ }^{*}$ Corresponding author
}

Keywords: College students, Supply chain management, Obtain employment.

\begin{abstract}
Under the popularization of higher education, the supply chain management of higher education is an important way to improve the efficiency of education. Based on the research on the employment of college graduates, this paper introduces the theory of supply chain management into the personnel training system of colleges and universities, regards colleges and universities as the core enterprises, regard the college enrollment, education and training, employment and other related departments as the nodes in the supply chain and builds higher education talents Supply chain model. The innovation of this survey links the related theories of supply chain management with the improvement of employability of university students, and finds out the common problems. At the same time, this paper uses a large amount of data for empirical analysis, building a new hierarchical system, more rigorous logic, more in-depth analysis. After investigation and analysis, we found that the current student skills and ideas and business needs do not match the problem. And put forward the suggestion that university-enterprise cooperation that needs the joint efforts of universities, society, enterprises and college students.
\end{abstract}

\section{Introduction}

Features and innovation: The survey applies the idea of supply chain management in enterprises to the talent cultivation quality evaluation system in colleges and universities. It connects the related theories of supply chain management with the improvement of employment ability of college students. It finds common problems and relatively matured supply chain management Experience to learn from the process of upgrading the employability of college students to go. At the same time, it uses a large amount of data to make an empirical analysis and builds a new hierarchical system, which is more logically rigorous and more in-depth analysis. It not only has a clear idea but also is conducive to the follow-up analysis and discussion of relevant countermeasures, and examines the quality of employment in Liaoning Province from a completely new perspective the situation of the school professional structure adjustment planning and planning have some guiding significance.

\section{Survey Program}

Using simple random sampling method, this paper analyzes the undergraduates and school teachers (including teachers and admissions and employment office teachers), managers and ordinary employees of enterprises in Liaoning Province from the source side, the production side, the market side, Aftermarket four aspects of investigation and analysis.

Determination of the best sample size: Stratified random sampling "211" colleges and universities, an ordinary one college, two colleges and three institutions are two, each of the sampling of schools were made by a simple random sampling, sampling of school students in the sample and classroom sample. In this simple random sampling process, we need to find the best sample size extracted from the sampling frames of each level 2 unit based on the total capacity, overall variance, population mean, relative allowable error and confidence level of each level 2 unit sampling frame. 


\section{Data Processing, Testing and Analysis}

1. Data processing and analysis methods

Purification of data and processing of missing values: Find and modify out-of-range, extreme-value, and logically inconsistent data after the entry, purify the data as follows: Use Analysis $\rightarrow$ Descriptive Statistics $\rightarrow$ Explore options to find outliers using SPSS $\rightarrow$ Use Analyze $\rightarrow$ "Descriptive Statistics" $\rightarrow$ "Crosstab" Clean up the mutex options and use the "Data" $\rightarrow$ "Identify duplicate cases" method to schedule duplicate cases.

For the processing of missing values, a small amount of missing values can be replaced by the mean of the values of the variables, and the entire questionnaire will be voided if most of the missing data in the questionnaire is missing.

Data analysis method: Adopted the inductive analysis, comparative analysis, structural analysis of the qualitative analysis and description of statistical analysis, analysis of variance, a linear regression, correlation analysis of the quantitative analysis of a combination of methods.

Highlight analysis of variance, a linear regression, correlation analysis: In studying the influencing factors of employment ability of university graduates in Liaoning Province, we need to conduct hypothesis testing and analysis of variance, classify the respondents according to the level of influencing factors, and study the differences of matching degree between different types of respondents so as to be able to base on this, significant influencing factors were introduced, and the model of virtual variables was established to study the effects of various influencing factors, which laid the foundation for the later conclusions and suggestions.

2. Student-based questionnaire analysis:

Table 1. College employment guidance ANOVA analysis

\begin{tabular}{c|c|c|c|c|c}
\hline \multicolumn{7}{c}{ ANOVA } \\
\hline & Sum of Squares & df & Mean square & F & Significance \\
\hline $\begin{array}{c}\text { Between } \\
\text { Groups }\end{array}$ & 729.905 & 3 & 243.302 & 110.028 & .000 \\
\hline $\begin{array}{c}\text { Within } \\
\text { Groups }\end{array}$ & 742.990 & 336 & 2.211 & & \\
\hline Total & 1472.894 & 339 & & & \\
\hline
\end{tabular}

In the above table, there is one row between groups, the sum of squares SSA $=729.905$, the degree of freedom $\mathrm{df}=\mathrm{k}-1=4-1=3, \mathrm{k}$ is the number of factors, that is, Mean Square MSA $=$ 243.302.

Within Groups, Sum of Squares SSE $=742.990$, degrees of freedom df $=n k=340-4=336$, where $\mathrm{n}$ is the number of all samples, Mean Square MSE $=2.211$.

Total line, Sum of Squares $=$ SSA + SSE $=729.905+742.990=1472.894$, degrees of freedom df $=\mathrm{n}-1=400-1=339$.

$\mathrm{F}$ statistic $=\mathrm{MSA} / \mathrm{MSE}=110.028, \mathrm{~F}$ statistic is greater than the critical value F0.05 $(3,336)$, indicating that it falls into the rejection domain. Sig value $=0.000<0.05$, rejected the null hypothesis, and considered that there were indeed significant differences in the number of employment guidance and services received by school-based students in the four types of colleges and universities.

3. Based on the production side of the questionnaire analysis: Analysis of variance in the number of teaching methods

Using the analysis method of table 1, we conclude that there are significant differences in the number of teaching methods adopted in the seven fields of specialization.

4. Market-based questionnaire analysis:

Using univariate regression analysis, we can get the non-standardized regression equation $\mathrm{y}=$ $1.519+0.064 \mathrm{x}$, and the actual employment of students and their expected degree of compliance $\mathrm{x}$ is the key factor affecting the management of university tracking management.

Standardized regression equation: $\mathrm{y}=0.085 \mathrm{x}$ 
5. Questionnaire analysis based on after sales:

Similarly, the following conclusions can be drawn from the methods in Table 1: The above results show that colleges and universities should pay more attention to finding a school-enterprise cooperation enterprise. The statistical results show that the "central SOEs, state-owned enterprises and institutions", "large privately-owned well-known companies" and "small and medium private-owned companies" Intentions are strong, while "Hong Kong, Macao and Taiwan funded enterprises" "foreign-funded enterprises" to accept the cooperation of the less. When seeking cooperation with enterprises, colleges and universities need to take into account their own professional types as well as the wishes of different types of enterprises. Thus, the success rate of focusing on "casting nets" will be even higher.

Table 2. Respondents students: the ranking frequency of emphasis on the employability of undergraduates

\begin{tabular}{|c|c|c|c|c|}
\hline & & \multicolumn{2}{|c|}{ response } & \multirow{2}{*}{ Case percentage } \\
\hline & & $\mathrm{N}$ & percentage & \\
\hline \multirow{6}{*}{$\begin{array}{l}\text { University students } \\
\text { employment ability order } \\
\text { of importance }{ }^{\mathrm{a}}\end{array}$} & Psychological quality & 90 & $15.7 \%$ & $78.9 \%$ \\
\hline & basic skills & 109 & $19.1 \%$ & $95.6 \%$ \\
\hline & professional skills & 114 & $19.9 \%$ & $100.0 \%$ \\
\hline & Self-development ability & 87 & $15.2 \%$ & $76.3 \%$ \\
\hline & team work & 86 & $15.0 \%$ & $75.4 \%$ \\
\hline & $\begin{array}{c}\text { Organizational } \\
\text { management skills }\end{array}$ & 86 & $15.0 \%$ & $75.4 \%$ \\
\hline \multicolumn{2}{|c|}{ Total } & 572 & $100.0 \%$ & $501.8 \%$ \\
\hline \multicolumn{5}{|c|}{ Group a } \\
\hline
\end{tabular}

Table 3. Respondents enterprise managers: ranking of employability of graduates

\begin{tabular}{|c|c|c|c|c|}
\hline & \multicolumn{2}{|c|}{ response } & \multirow{2}{*}{ Case percentage } \\
\hline & & $\mathrm{N}$ & percentage & \\
\hline \multirow{6}{*}{$\begin{array}{l}\text { University students } \\
\text { employment ability } \\
\text { order of importance }\end{array}$} & $\begin{array}{l}\text { Psychological } \\
\text { quality }\end{array}$ & 264 & $14.8 \%$ & $80.0 \%$ \\
\hline & basic skills & 276 & $15.5 \%$ & $83.6 \%$ \\
\hline & professional skills & 321 & $18.0 \%$ & $97.3 \%$ \\
\hline & $\begin{array}{l}\text { Self-development } \\
\text { ability }\end{array}$ & 288 & $16.2 \%$ & $87.3 \%$ \\
\hline & team work & 331 & $18.6 \%$ & $100.3 \%$ \\
\hline & $\begin{array}{c}\text { Organizational } \\
\text { management skills }\end{array}$ & 302 & $16.9 \%$ & $91.5 \%$ \\
\hline \multicolumn{2}{|l|}{ total } & 1782 & $100.0 \%$ & $540.0 \%$ \\
\hline
\end{tabular}

Students and teachers believe that the most important proportion of professional skills, while the survey results of business people has shown that they pay more attention to the ability to develop. The difference between the two must be reflected in the existing quality of graduates and the mismatch between the employer and the quality requirements, which is also a major factor affecting the employability of college students.

\section{Investigating the Main Conclusions}

Based on the findings of the students, producers, markets and sales terminals, the following conclusions are drawn: (1)Students majoring in school and school are not their favorite. (2)Teachers traditional teaching methods can not meet the students hope to increase teaching experiment and practice of voice. In addition, career guidance teachers are not professional enough. (3)Students' concept of employment is inconsistent with that of employers, which leads to the frustration of 
students in the job market. There are also some graduates forced employment pressure can only rush to choose not are suitable for their own business and occupation. (4)Students and teachers consider professional skills to be the most important, but the findings of both general and corporate managers show that they are more focused on developing their abilities.

\section{Suggestions}

\section{Source side}

(1) Colleges and universities improve the enrollment publicity management system

First of all, on the one hand, the enrollment plan should be linked with the market demand; on the other hand, colleges and universities should formulate detailed and operable enrollment and propaganda programs. Through various channels such as interpersonal media, electronic media and print media comprehensive use and clever mix, maximize the radiation surface, so that the campus image enjoys popular support. Second, the need to establish a strong recruiting team to establish an all-round information exchange platform. For example, open campus day, college entrance examination counseling, summer camp activities, school trips and so on. All colleges and universities can set the evaluation system of candidates according to their own needs, and carefully carry out screening and evaluation of students.

(2) Students reasonable choice of institutions and professional

We can launch college campus tourism project, not only online contrast and access to institutions of higher learning and professional teachers, scientific research level, training programs, admission scores and other details, you can also buy campus tour packages with college students in the guide under the leadership of the line under the advance experience.

(3) Reform and perfect the college entrance examination system

In the college entrance examination process to increase the interview link, a better comprehensive observation of students' comprehensive ability. At the same time, it is recommended to adopt multiple assessment, comprehensive assessment of the way to increase the proportion of daily learning assessment activities.

2. Production side

(1) Strengthen the practice of teaching the fall of the ground, the establishment of "school-enterprise cooperation" school mode

On the one hand, we should step up the practical teaching and actively invite the society and enterprises to participate in the teaching management of the school, strengthen the contact and cooperation with the government and enterprises, and set up the second classroom activities. On the other hand, strengthening the ground-breaking practice activities. Finally, the establishment of school-enterprise cooperation mode of education, the establishment of student internships, internships base, hire business staff to visit the school to guide the school operating skills, and regularly send students to visit the business internship, real feel business atmosphere and operation management mechanism, understanding of knowledge, to stimulate students' professional interest.

(2)Adjust the professional structure and teaching mode, cultivate special talents, improve the examination system of students and teachers, and improve the employment guidance system.

\section{Market side}

Colleges and universities should pay attention to the marketing of talents, properly carry out the marketing of talents, regulate the system of recruitment on campus, establish the information platform of talent supply chain and standardize the statistical system of employment rate. Undergraduates establish a correct concept of employment and establish proper employment expectations. Establish a correct concept of recruitment of enterprises, set a unified system of recruitment and selection of personnel.

\section{Aftermarket}

On the one hand, colleges and universities attach importance to after-sales service, real-time tracking management to reflect the success or failure of training methods. We can make up for the shortage by retraining our graduates, and more importantly, we can train students to more specific by adjusting their training programs. On the other hand, enterprises should make positive feedback 
to colleges and universities so that colleges and universities can make reasonable adjustments to follow-up talents even if they can make up for the deficiencies.

\section{References}

[1] Ma Xiaohong. From the talent supply chain perspective on employment bottlenecks [J]. Occupation Circle, 2007, (No. 8).

[2] ZHOU Ning, ZHANG Wen-hua. Feasibility Analysis of Implementing Supply Chain Management in Employment Work in Colleges and Universities [J]. China Adult Education, 2014, (No. 23).

[3] Gu Hong, Song Changchun. Based on the supply chain theory of applied undergraduate college students employment mode of cultivation [J]. Higher Agricultural Education, 2013, (No. 9).

[4] Wang Wei. Construction of Career Guidance Course System for Higher Vocational Graduates from the Perspective of Supply Chain [J]. Journal of Wuhu Vocational Technical College, 2013, (No. 1)

[5] Liu Yougeng. Employment Strategy Analysis of Higher Vocational College Students from the Perspective of Supply Chain Management [J]. Business, 2012, (No. 43).

[6] Li Peng. Talent supply chain management model [J]. Human Resource Management, 2016, (No. $3)$.

[7] Journal of Huaihai Institute of Technology (Humanities and Social Sciences), 2014, (No.10)

[8] Wang Jichun. Research on the Operational Model of Local Universities Based on Talent Supply Chain $[\mathrm{J}]$. 